\title{
Valorization of Eucalyptus nitens bark by organosolv pretreatment for the production of advanced biofuels
} \author{
José A. Teixeira ${ }^{a}$, Lucília Domingues ${ }^{a}$ \\ ${ }^{a}$ CEB-Centre of Biological Engineering, University of Minho, Campus Gualtar, Braga, Portugal \\ ${ }^{\mathrm{b}}$ Chemical Engineering Department, EEI, University of Vigo, Campus Vigo, Vigo, Spain \\ ${ }^{c}$ Chemical Engineering Department, Faculty of Science, University of Vigo, Campus Ourense, Ourense, Spain \\ ${ }^{\mathrm{d}}$ CITI-Tecnopole, San Ciprián de Viñas, Ourense, Spain
}

Aloia Romaní ${ }^{\mathrm{a}, *}$, Antonio Larramendi ${ }^{\mathrm{b}}$, Remedios Yáñez ${ }^{\mathrm{c}, \mathrm{d}}$, Ángeles Cancela ${ }^{\mathrm{b}}$, Ángel Sánchez ${ }^{\mathrm{b}}$,

\section{A R T I C L E I N F O}

\section{Keywords:}

Eucalyptus nitens bark

Organosolv

Bioethanol

Simultaneous saccharification and

fermentation

Delignification

\begin{abstract}
A B S T R A C T
The biofuels production from alternative and renewable raw materials is mandatory to achieve sustainable growth based on a bioeconomy. Eucalyptus bark is a waste generated during the chemical manufacturing of Eucalyptus pulp that can be used as an alternative source of biomass, suitable for the production of biofuels. In this work, Eucalyptus nitens bark (ENB) was fractionated by organosolv treatment for ethanol production. For that, a Doehlert experimental design was carried out to evaluate the dependent variables: temperature $\left(170-200{ }^{\circ} \mathrm{C}\right)$, time $(30-90 \mathrm{~min})$ and ethanol-water percentage $(50-80 \%)$ on delignification of Eucalyptus bark. Organosolv process was suitable for the fractionation of $E$. nitens bark. After treatment, 74-93 \% of glucan was recovered and $25-52 \%$ of delignification was achieved. Delignified ENB was subjected to simultaneous saccharification and fermentation process for bioethanol production. The results showed that the variables temperature and time of organosolv process had significant influence on ethanol production. The organosolv pretreatment improved the ethanol yield from 32 to $99 \%$. This work shows a suitable process for the valorization of Eucalyptus bark into bioethanol.
\end{abstract}

\section{Introduction}

The increasing worldwide population coupled with the industrialization and the development of emerging economies result in increasing energy demand (Dafnomilis et al., 2017). This contributes to our strong dependence on fossil fuels and to increase greenhouse gas (GHG) emissions to the atmosphere, which lead the scientific community to seek and promote the use of alternative, sustainable and clean energy sources (Küüt et al., 2017). In line with this, a number of European Directives dealing with the biofuel use have emerged, namely: Renewable Energy Directive 2009/28/EC (RED) and Fuel Quality Directive 2009/30/EC, recently amended by the EU Directive 2015/1513 (Küuit et al., 2017). The RED sets by 2020 a $20 \%$ of renewable energy sources in final energy consumption, a $20 \%$ increase in energy efficiency and $10 \%$ of renewable energy sources (including biofuels) in transport sector. Additionally, the Directive (EU) 2015/1513 goes one step further, regulating the indirect land-use change effects of biofuels production, and limiting to $7 \%$ the contribution of conventional fuels (for example, produced from food crops such as corn, wheat, sugarcane, sugar beet pulp, palm oil, etc.), to reach the $10 \%$ target introduced by RED for 2020 (Dafnomilis et al., 2017). Therefore, this directive promotes the second-generation biofuels or advanced biofuels, based on alternative raw materials such as lignocellulosic materials (LCM) including energy crops (miscanthus, jatropha, etc.), fast growing species (such as Eucalyptus, poplar, pine, Leucaena, Sesbania, Paulownia) and forestry and agro-industrial byproducts (Ruiz et al., 2013; Domec et al., 2017).

For suitable lignocellulose-to-ethanol process, a pretreatment is mandatory (enabling the selective separation of the main components, including cellulose, hemicelluloses and lignin) in the scope of biomass biorefinery (Romaní et al., 2011). Therefore, the main steps involved for bioethanol production are: i) size reduction; ii) pretreatment; iii) saccharification; iv) fermentation and v) distillation of the fermentation broth (Romaní et al., 2013; Yáñez-S et al., 2013; Alvira et al., 2010; Galbe and Zacchi, 2007).

Several treatments have been employed for the fractionation of biomass, including physical, physico-chemical or biological pretreatments (Kumar and Sharma, 2017; Galbe and Zacchi, 2007).

\footnotetext{
* Corresponding author.

E-mail address: aloia@ceb.uminho.pt (A. Romaní).
} 
Unfortunately, most of these biomass pretreatments lead to relatively low sugar yield and product concentration due to a significant lignin fraction that remains in the pretreated biomass (Zhao et al., 2017). Delignification process can increase the cellulose content in the pretreated biomass, which is of great importance to obtain higher glucose concentration in the hydrolysates. In this context, the delignification of several LCM by organosolv treatments (Domínguez et al., 2014; Kim et al., 2010; Muñoz et al., 2007; Pan et al., 2006) using organic solvents (including ethanol, methanol, acetone, glycerol, etc.), or mixture of solvent-water (with or without addition of catalysts) (Martín et al., 2011) has been proposed. The advantages of organosolv pretreatment includes: i) the considerable improvement into cellulose-to-glucose conversions in later stages of saccharification, ii) the easy recovery of organic solvents (by flashing the cooking liquors), and their subsequent reuse, iii) the partial hemicelluloses solubilization and therefore, the recovery of hemicellulosic oligosaccharides, sugars and furfural from the liquors and iv) the isolation of high-quality sulfur-free lignin, with desirable properties. This approach allows further valorization of major LCM components to produce renewable fuels and fine chemicals in a biorefinery scheme (Yáñez-S et al., 2013; Zakzeski et al., 2012; Toledano et al., 2011,2012; Muñoz et al., 2011; El Hage et al., 2011). Additionally, it should be taken into account that the cited co-products generated in the organosolv process, would improve the economic sustainability and the flexibility of the process (Muñoz et al., 2011). The later information, combined with the low environmental impact of the organosolv process, its high pulp yields and the limited investment required establishing new plants (Saberikhah et al., 2011), making it possible for this technology to have a promising future in the scope of biomass biorefinery (Zhao et al., 2017).

On the other hand, the saccharification and fermentation stages can be carried out sequentially or simultaneously. In comparison with the separate hydrolysis and fermentation, the simultaneous saccharification and fermentation (SSF) presents some advantages such as the reduction of operational cost (associated with the operation in a single reactor, the reduction of enzyme loads and the increase in the productivity), as well as the decrease of substrate inhibition and the contamination risks (due to the lower accumulation of sugars in the fermentation broth) (Chen et al., 2007; Rohowsky et al., 2013; Yáñez-S et al., 2013; Romaní et al.,2016).

Eucalyptus is a fast-growing tree, with a great demand in the pulp and paper industry (Li et al., 2013; Penín et al., 2018); since it is extensively used as raw material, for instance, in Kraft pulping process (Rodríguez-López et al., 2012). According to data provided by Flynn (2010), the total plantation area estimated for eucalyptus tree in the world is between 16 and 19 million hectares (40-47 million acres) with a production of 15-25ton/ha/year (Lima et al., 2013). The predominant specie is Eucalyptus globulus wood. Nevertheless, the presence of some insect plagues and fungi in the $E$. globulus has caused that $E$. nintes has emerged as alternative to E. globulus (Pérez et al., 2006). Moreover, E. nitens is able to survive at low temperatures (GonzálezGarcía et al., 2013) and a regional study showed the energy potential of E. nintes when used for biomass production (Pérez et al., 2006). During the chemical manufacturing of eucalyptus pulp, large amounts of wastes are produced, such as leaves, branches, barks, cross-cut ends and out-of-specification wood chips, which are left in the field to enrich the soil or burned for electricity or heat production (Lima et al., 2013; Moshkelani et al., 2013). Among these residues, bark represents the $10-12 \%(\mathrm{v} / \mathrm{v})$ of the total biomass harvested (Lima et al., 2013). This amount of residues means that 20 tons of bark can be generated in a pulp mill per 100 tons of pulps produced (Neiva et al., 2018). Therefore, eucalyptus bark has been recently identified as novel source of biomass with potential for bioethanol production (Neiva et al., 2018; Zhu and Pan, 2010; Lima et al., 2013; Foelkel, 2010). However, only a few studies have been reported on the valorization of the eucalyptus bark. Canettieri and co-workers (2007) optimized the diluted sulfuric acid hydrolysis of Eucalyptus grandis residues (branches, foliage and bark) in a pilot scale reactor. Matsushita et al. (2010) assayed the influence of the hydrothermal pretreatment with carbon dioxide on the enzymatic saccharification of Eucalyptus globulus bark. Lima et al. (2013) reported on the potential of two commercial eucalyptus clones (Eucalyptus grandis and hybrid E. grandis- E. urophylla) for the production of biofuel. They studied the effects of delignification processes with increasing sodium hydroxide concentrations, preceded or not by diluted acid, as well as the enzymatic digestibility of the pretreated solids. In a later study, Lima et al. (2014) compared the potential of alternative raw materials such as several grasses and eucalyptus barks (from Eucalyptus grandis and hybrid E. grandis- urophylla) against sugar cane bagasse as raw materials for bioethanol production.

To our knowledge, no studies on the pretreatment of Eucalyptus nitens bark focused on the biofuels production have been reported. Therefore, the aim of this study was the valorization of $E$. nitens bark as raw material for bioethanol production by organosolv pretreatment without catalyst. Experimental design was proposed for evaluation of operational conditions of process (temperature, time and ethanol-water percentage) on fractionation of $E$. nitens bark and to improve the ethanol production by simultaneous saccharification and fermentation using an industrial Saccharomyces cerevisiae strain.

\section{Materials and methods}

\subsection{Raw material and chemical composition analysis}

Eucalyptus nitens bark (ENB) samples were kindly provided by a local pulp mill (ENCE, Pontevedra, Spain). Air-dried samples were milled and sieved to pass a $1 \mathrm{~mm}$ screen and stored in a dry place until be used.

The chemical characterization of ENB (included in Table 1) was determined following the procedures.The raw material was milled to particle sizes $<0.5 \mathrm{~mm}$ (IKA M-20 grinder, Germany) and assayed for moisture (TAPPI T-264 om-88 method), and extractives (TAPPI T-264 om- $88 \mathrm{~m}$ ) and ashes (T-211 om-93 method) in a muffle furnace at $525^{\circ} \mathrm{C}$. Chemical composition of ENB and pretreated ENB was determined following the TAPPI T $249 \mathrm{~cm}-85$ method. Approximately, $0.5 \mathrm{~g}$ of ENB was weighted and treated with $5 \mathrm{~mL}$ of $72 \%$ (w/w) $\mathrm{H}_{2} \mathrm{SO}_{4}$, stirring at $30^{\circ} \mathrm{C}$. After that, the acid solution was diluted to a $4 \%$ concentration and was submitted to hydrothermal treatment $\left(121^{\circ} \mathrm{C}\right.$ for $1 \mathrm{~h}$ ) in autoclave to complete the hydrolysis of oligosaccharides. The liquors were analysed by high performance liquid chromatography (HPLC) for the glucose, xylose, arabinose and acetic acid quantification for cellulose, xylan, arabinan and acetyl groups determination. The samples were analysed by HPLC with a refractive index detector (Jasco) and Aminex HPX-87H (BioRad, USA) column eluted with $0.005 \mathrm{M}$ $\mathrm{H}_{2} \mathrm{SO}_{4}$, flow rate of $0.6 \mathrm{~mL} / \mathrm{min}$ at $60^{\circ} \mathrm{C}$. The solid obtained in the filtration after acid hydrolysis (TAPPI T-249 cm-85) was oven-dried and weighed (TAPPI T-222 om-98) for the determination of acid insoluble residue content. The acid soluble lignin (ASL) content was quantified by spectrophotometry at $205 \mathrm{~nm}$ following the procedure described in

Table 1

Chemical composition of Eucalyptus nitens bark.

\begin{tabular}{ll}
\hline Component & (g/100 g dry wood) \\
\hline Glucan & $45.27 \pm 0.94$ \\
Hemicelluloses & 16.64 \\
Xylan & $12.72 \pm 0.82$ \\
Arabinan & $1.17 \pm 0.08$ \\
Acetyl Group & $2.75 \pm 0.02$ \\
Acid Insoluble lignin (Klason Lignin) & $21.96 \pm 0.65$ \\
Acid Soluble Lignin (ASL) & $6.73 \pm 0.15$ \\
Extractives & $4.95 \pm 0.46$ \\
Ashes & $5.18 \pm 0.98$ \\
Sum & 100.73 \\
\hline
\end{tabular}


Table 2

Experimental design expressed in terms of the dimensional variables temperature, time and ethanol-water percentage and dimensionless variables $x_{1}, x_{2}$ and $\mathrm{x}_{3}$.

\begin{tabular}{|c|c|c|c|c|c|c|}
\hline \multirow[t]{2}{*}{$\begin{array}{l}\text { Experiment } \\
\text { number }\end{array}$} & \multicolumn{3}{|c|}{ Dimensional independent variables } & \multicolumn{3}{|c|}{$\begin{array}{l}\text { Dimensionless, normalized, } \\
\text { independent variables }\end{array}$} \\
\hline & Temperature $\left({ }^{\circ} \mathrm{C}\right)$ & $\begin{array}{l}\text { Time } \\
\text { (min) }\end{array}$ & $\begin{array}{l}\text { Ethanol- } \\
\text { water } \\
(\%)\end{array}$ & $\mathrm{x}_{1}$ & $\mathrm{x}_{2}$ & $\mathrm{x}_{3}$ \\
\hline 1 & 200 & 60 & 65 & 1 & 0 & 0 \\
\hline 2 & 170 & 60 & 65 & -1 & 0 & 0 \\
\hline 3 & 192.5 & 34.0 & 65 & 0.5 & -0.866 & 0 \\
\hline 4 & 192.5 & 86.0 & 65 & 0.5 & 0.866 & 0 \\
\hline 5 & 192.5 & 51.3 & 77.2 & 0.5 & -0.289 & 0.817 \\
\hline 6 & 192.5 & 68.7 & 52.8 & 0.5 & 0.289 & -0.817 \\
\hline 7 & 177.5 & 51.3 & 77.2 & -0.5 & -0.289 & 0.817 \\
\hline 8 & 177.5 & 86.0 & 65.0 & -0.5 & 0.866 & 0 \\
\hline 9 & 177.5 & 34.0 & 65.0 & -0.5 & -0.866 & 0 \\
\hline 10 & 177.5 & 68.7 & 52.8 & -0.5 & 0.289 & -0.817 \\
\hline 11 & 185 & 42.7 & 52.8 & 0 & -0.577 & -0.817 \\
\hline 12 & 185 & 77.3 & 77.2 & 0 & 0.577 & 0.817 \\
\hline 13 & 185 & 60 & 65 & 0 & 0 & 0 \\
\hline 14 & 185 & 60 & 65 & 0 & 0 & 0 \\
\hline 15 & 185 & 60 & 65 & 0 & 0 & 0 \\
\hline
\end{tabular}

Dávila et al. (2017). All the analyses were carried out in triplicate.

\subsection{Processing of Eucalyptus nitens bark: experimental design}

ENB samples were submitted to organosolv delignification process with ethanol-water solutions. Table 2 summarizes the Doehlert experimental plan designed to assess the effects of the independent variables (temperature, time and percentage of ethanol) on the chemical composition of the pretreated solids and their susceptibility to further simultaneous saccharification and fermentation (SSF) experiments to produce ethanol. The experimental data were fitted to the proposed equations using commercial software (Microsoft Excel, Redmon, Washington, USA).

A $2 \mathrm{~L}$ stainless steel Parr reactor (Parr Instruments Company, Moline, Illinois, USA), was used for organosolv treatments. The reactor was fitted with two four-blade turbine impellers, heated by an external fabric mantle and cooled by cold water circulating through an internal stainless-steel loop. Temperature was controlled using a PID module, model 4842 (Parr Instruments Company, Moline, Illinois, USA). The raw material, water and ethanol were mixed in the reactor to obtain a liquor to solid ratio of $8 \mathrm{~g} / \mathrm{g}$ under experimental conditions listed in Table 2 . The reactor was heated to reach the desired temperature and the reaction media were stirred at $150 \mathrm{rpm}$. The experiment was carried out for the desired time (listed in Table 2).

At the end of the treatments, the reactor was rapidly cooled and the solids were recovered by filtration and washed first with ethanol at room temperature solution (to remove the adsorbed lignin and others compounds from solid surface) and after with abundant distilled water. Afterwards, solids were weighed for solid yield (SY) determination (expressed as g pretreated solid recovered/100 g raw material, on dry basis). Solids were analysed using the methods summarized in section 2.1. Aliquots of liquors were subjected to quantitative post-hydrolysis with $\mathrm{H}_{2} \mathrm{SO}_{4}(4 \% \mathrm{w} / \mathrm{w})$ at $121^{\circ} \mathrm{C}$ for $20 \mathrm{~min}$. The samples were analysed by HPLC for sugars determination as mentioned in section 2.1 .

\subsection{Microorganism and inoculum preparation}

Saccharomyces cerevisiae PE-2 strain isolated from Brazilian Bioethanol Distillery was used in this work (Pereira et al., 2014). The strain was maintained on yeast peptone dextrose ( $2 \%$ of glucose, $2 \%$ of peptone and $1 \%$ of yeast extract) agar medium at $4{ }^{\circ} \mathrm{C}$. Yeast was grown in Erlenmeyer flasks containing $20 \mathrm{~g} / \mathrm{L}$ of glucose, $20 \mathrm{~g} / \mathrm{L}$ of peptone and $10 \mathrm{~g} / \mathrm{L}$ of yeast extract for $15 \mathrm{~h}$ at $30^{\circ} \mathrm{C}$ and $200 \mathrm{rpm}$. Cells were separated from culture media by centrifugation $\left(10 \mathrm{~min}\right.$ at $4{ }^{\circ} \mathrm{C}$ and $7500 \mathrm{~g}$ ) and resuspended in $0.9 \% \mathrm{NaCl}$. The simultaneous saccharification and fermentation (SSF) experiments were inoculated with $5 \mathrm{~g}$ of fresh yeast / L (final concentration).

\subsection{Simultaneous saccharification and fermentation}

The delignified solids were subjected to SSF experiments in $100 \mathrm{~mL}$ Erlenmeyer flasks with a working volume of $40 \mathrm{~mL}$ in an orbital shaker. The solution containing nutrients $(20 \mathrm{~g} / \mathrm{L}$ of peptone and $10 \mathrm{~g} / \mathrm{L}$ of yeast extract) and pretreated solids were sterilized separately in autoclave at $121^{\circ} \mathrm{C}$ for $15 \mathrm{~min}$. Enzyme concentrates (Cellic Ctec2 and Cellic Htec2) were kindly provided by Novozyme (Denmark). Enzymatic activities were determined as described by Ghose (1987) and Bailey et al. (1992) and corresponded to 120 FPU (Filter Paper Units)/mL and 1690 IU (International Units) $/ \mathrm{mL}$, respectively. SSF started after mixing the nutrients and $10 \%$ of pretreated solids and adding the inoculum and enzymes to the media. All the SSF experiments were carried out at $35^{\circ} \mathrm{C}$ and $150 \mathrm{rpm}$. The SSF assays were performed with an enzyme load of $25 \mathrm{FPU} / \mathrm{g}$ of substrate for Cellic CTec2 and $8 \mathrm{UI} / \mathrm{FPU}$ for Cellic HTec2 and inoculated with $5 \mathrm{~g}$ of fresh yeast $/ \mathrm{L}$. At given reaction times, samples were withdrawn from the reaction media, centrifuged, filtered and analysed by HPLC for glucose, xylose, acetic acid and ethanol concentration (see below). Ethanol yield $\left(\mathrm{Y}_{\mathrm{Et}}\right)$ was calculated by the following equation:

$Y_{E t}(\%)=\frac{\text { Ethanol }_{f}-\text { Ethanol }_{0}}{0.51 f \text { B } 1.111} 100$

where, Ethanol $\mathrm{f}_{\mathrm{f}}$ is the ethanol concentration produced during the fermentation $(\mathrm{g} / \mathrm{L})$, Ethanol ${ }_{0}$ is the ethanol concentration at the beginning of the fermentation ( $\mathrm{g} / \mathrm{L}$ ) which was zero, B is dry biomass concentration at the beginning of the fermentation $(\mathrm{g} / \mathrm{L})$, f is glucan fraction of delignified Eucalyptus nitens bark ( $\mathrm{g}$ glucan per $\mathrm{g}$ delignified bark, on dry basis, see Table 3 for experimental values), 0.51 is conversion factor for glucose to ethanol based on stoichiometric biochemistry of yeast. The stoichiometric factor that converts glucan to equivalent glucose is 1.111 .

\section{Results and discussion}

\subsection{Chemical composition of the raw material}

The chemical composition of the Eucalyptus nitens bark (ENB) (expressed in $\mathrm{g}$ per $100 \mathrm{~g}$ wood on an oven-dry basis \pm standard deviation) is detailed in Table 1 . As seen, ENB is composed mainly by polysaccharides (closed to $60 \%$ ) followed by Klason lignin (21.96\%). Therefore, the high polysaccharide content shows its potential as raw material for bioconversion into chemicals and fuels. In order to complete the characterization, other components were also determined, such as acetyl groups and extractives, which accounted for 2.75 and $4.95 \%$, respectively. The ash content $(5.18 \%)$ present in bark is overall higher than ash in wood (Neiva et al., 2018; Penín et al., 2018). The results are in accordance with the chemical composition of Eucalyptus globulus bark (Neiva et al., 2018). Nevertheless, lower content in glucan and xylan and slightly higher Klason lignin $(37.1 \%, 9.8 \%$ and $24.4 \%$, respectively) were recently reported for Eucalyptus dunnii bark by Reina et al. (2016). On the other hand, Klason lignin and xylan content were lower when comparing to wood from hardwoods such as Eucalyptus globulus wood and Acacia dealbata wood (Romaní et al., 2010; Domínguez et al., 2014). These differences were also reported by Neiva et al. (2018), who compared wood chips and bark from Eucalyptus globulus wood. 
Table 3

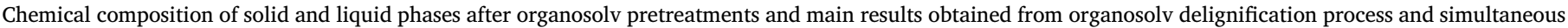
saccharification and fermentation (SSF) of delignified Eucalyptus nitens bark.

\begin{tabular}{|c|c|c|c|c|c|c|c|c|c|c|c|}
\hline \multirow[t]{3}{*}{ Experiments } & \multicolumn{5}{|c|}{ Main Results of Chemical composition } & \multicolumn{4}{|c|}{ Main Results of Organosolv fractionation } & \multicolumn{2}{|c|}{ Main Results of SSF process } \\
\hline & \multicolumn{3}{|c|}{ Solid phase (\%) } & \multicolumn{2}{|c|}{ Liquid phase (g/L) } & \multirow{2}{*}{$\begin{array}{l}\text { SY } \\
\text { or y1 }\end{array}$} & \multirow{2}{*}{$\begin{array}{l}\% \text { Delignification } \\
\text { or y2 }\end{array}$} & \multirow{2}{*}{$\begin{array}{l}\text { Gn recovery } \\
\text { or y3 }\end{array}$} & \multirow{2}{*}{$\begin{array}{l}\text { Xn recovery } \\
\text { or y4 }\end{array}$} & \multirow{2}{*}{$\begin{array}{l}\text { Ethanolmax } \\
\text { or y5 }\end{array}$} & \multirow{2}{*}{$\begin{array}{l}\text { Ethanol yield } \\
\text { or y6 }\end{array}$} \\
\hline & Gn & $\mathrm{Xn}$ & KL & $\mathrm{XDC}$ & GDC & & & & & & \\
\hline 1 & 65.31 & 6.39 & 17.99 & 4.58 & 0.00 & 61.70 & 49.45 & 89.01 & 31.01 & 28.25 & 82.61 \\
\hline 2 & 52.77 & 14.03 & 21.05 & 3.86 & 1.12 & 77.17 & 26.00 & 89.96 & 85.16 & 9.85 & 35.53 \\
\hline 3 & 57.99 & 9.27 & 19.84 & 8.45 & 1.20 & 68.42 & 38.18 & 87.66 & 49.87 & 16.70 & 54.89 \\
\hline 4 & 64.61 & 7.41 & 18.76 & 8.52 & 1.30 & 56.67 & 51.58 & 80.88 & 33.02 & 32.53 & 98.73 \\
\hline 5 & 55.90 & 13.54 & 21.94 & 8.33 & 1.18 & 65.21 & 34.83 & 80.53 & 69.42 & 10.59 & 36.06 \\
\hline 6 & 65.27 & 6.30 & 19.81 & 4.11 & 1.00 & 53.51 & 51.72 & 77.16 & 26.50 & 23.01 & 67.20 \\
\hline 7 & 50.34 & 14.02 & 21.22 & 4.26 & 0.84 & 77.67 & 24.93 & 86.38 & 85.65 & 9.02 & 34.13 \\
\hline 8 & 60.37 & 10.45 & 19.85 & 8.65 & 1.30 & 69.39 & 37.27 & 92.54 & 57.00 & 17.10 & 53.98 \\
\hline 9 & 53.85 & 14.53 & 20.18 & 6.78 & 0.93 & 74.32 & 31.69 & 88.40 & 84.89 & 8.91 & 31.53 \\
\hline 10 & 56.61 & 8.65 & 21.43 & 9.12 & 1.30 & 59.07 & 42.34 & 73.87 & 40.19 & 15.73 & 52.88 \\
\hline 11 & 58.37 & 7.90 & 20.44 & 3.62 & 1.11 & 61.41 & 42.82 & 79.18 & 38.16 & 18.55 & 60.53 \\
\hline 12 & 54.72 & 9.54 & 21.12 & 4.36 & 0.95 & 64.45 & 38.00 & 77.90 & 48.32 & 11.49 & 39.98 \\
\hline 13 & 56.83 & 9.06 & 21.19 & 6.61 & 1.03 & 63.92 & 38.32 & 80.25 & 45.54 & 16.73 & 58.62 \\
\hline 14 & 57.26 & 10.84 & 20.56 & 7.10 & 1.01 & 63.63 & 40.42 & 80.49 & 54.24 & 17.24 & 54.41 \\
\hline 15 & 56.51 & 9.78 & 20.13 & 8.76 & 1.32 & 63.29 & 41.99 & 79.01 & 48.65 & 16.50 & 53.63 \\
\hline
\end{tabular}

Gn: Glucan; Xn: Xylan; KL: Klason lignin; XDC: xylan derived compounds; GDC: glucan derived compounds.

\subsection{Experimental plan and chemical composition of the solids and liquid phases obtained after the organosolv pretreatment}

In this study, organosolv technology was selected for the processing of ENB based on previous works with Eucalyptus globulus wood for bioethanol production (Romaní et al., 2011, 2013; Romaní et al., 2016) and on the literature on fractionation treatment of lignocellulosic biomass (Wildschut et al., 2013).

A set of preliminary experiments (Table S1, supplementary material) was carried to identify the most influential variables (both in the delignification and SSF stages) and their range of interest. On basis of these results and to assess the potential of ENB as raw material for the bioethanol production, a Doehlert experimental design of 15 experiments was proposed (see experimental plan in Table 2). The selected independent variables were temperature $\left(\mathrm{T},{ }^{\circ} \mathrm{C}\right.$ or $\left.\mathrm{x}_{1}\right)$, time $(\mathrm{t}, \mathrm{min}$ or $\mathrm{x}_{2}$ ) and percentage of ethanol (ethanol-water, $\%$ or $\mathrm{x}_{3}$ ) and the variation ranges considered were: $170-200{ }^{\circ} \mathrm{C}, 30-90 \mathrm{~min}$ and $50-80 \%$ of ethanol-water, respectively. The Doehlert experimental design was selected in the basis of advantages over other second-order designs such as Central Composite and Box-Behnken since the number of experiments to complete the optimization process is lower than the other designs (Caldas et al., 2013).

The removal of lignin and hemicelluloses during organosolv pretreatment leads to improved enzymatic digestibility of cellulose and lower irreversible absorption of enzyme to lignin, resulting also in higher cellulose to glucose yields (Huijgen et al., 2011; Wildschut et al., 2013). In this sense, the objective of the selected pretreatment was to obtain delignified biomass with high polysaccharides contents (which could result in high potential sugar concentrations) and to improve the enzymatic saccharification of ENB. Table 3 shows the main results obtained after treatments: solid yields (SY) and chemical composition of the solid (delignified ENB) and liquid (black liquor) phases. As seen in Table 3, all the experimental conditions assayed resulted in solid yield higher than $53.5 \%$ (value corresponding to experiment 6 , which was carried out at medium temperatures and reaction times and low ethanol loads). The decrease of SY is related to higher solubilization of lignin and hemicellulosic fractions in organosolv delignification processes (Romaní et al., 2013). The highest solid yields ( $>77 \%$ ) were obtained in experiments 2 and 7, performed at $170{ }^{\circ} \mathrm{C}, 60 \mathrm{~min}$, and $65 \%$ ethanolwater and $117.5^{\circ} \mathrm{C}, 51.3 \mathrm{~min}$ and $77.2 \%$, respectively. As a general trend, an increase of temperature had a negative influence on the solid yield (Table 3).
Concerning the solid phase composition after delignification pretreatment (Table 3), the percentage of glucan varied from 50.3 to $65.3 \mathrm{~g}$ glucan $/ 100 \mathrm{~g}$ of pretreated ENB. The highest glucan content (corresponding to experiment 1 ) also resulted in the minimum Klason lignin content obtained (17.99\%). This increment of glucan allowed an enrichment of 1.44-fold higher glucan respect to the raw material. The increase of temperature yielded a pretreated ENB composed with higher glucan and lower xylan and Klason lignin, operating at intermediate time $(60 \mathrm{~min})$ and percentage of ethanol $(65 \%)$. This behavior was more pronounced at high temperatures (experiment 1, 2 and 13-15). Moreover, the increase of delignification time also contributed to the increase of glucan content in the pretreated biomass, as seen when comparing experiments 3 and 4 (temperature of $192.5^{\circ} \mathrm{C}$ and $65 \%$ of ethanol-water) and experiments 8 and 9 (temperature of $177.5^{\circ} \mathrm{C}$ and ethanol percentage of 65\%).

Hemicellulosic fraction of ENB (Table 1) is composed mainly by xylan, which represented the $76.4 \%$ of identified compounds. Xylan after organosolv treatment varied in the range of 6.30-14.53 $\mathrm{g}$ of xylan/ $100 \mathrm{~g}$ of delignified ENB. The xylan solubilization was influenced by temperature and percentage of ethanol. As a general trend, xylan content was lower than $10 \%$ at temperatures $>192.5^{\circ} \mathrm{C}$ and percentages of ethanol-water $<77 \%$ (Table 3 ). This fact could be related to typical behavior of hydrothermal treatment, influenced by high water content (Novo et al., 2011; Garrote et al., 1999).

On the other hand, Klason lignin content of pretreated ENB remained in a range from 17.99 to $21.94 \mathrm{~g}$ of Klason lignin/100 $\mathrm{g}$ of delignified ENB in all the experimental conditions tested in the proposed design. In order to evaluate the effect of organosolv process on delignification of Eucalyptus nitens bark, the percentage of delignification was calculated as follows:

$\%$ Delignification $(D)=100 \cdot \frac{K L_{r m}-K L_{D} S \cdot \frac{S Y}{100}}{K L_{r m}}$

where $K L_{\mathrm{rm}}$ and $K L_{\mathrm{DS}}$ are the percentages of Klason lignin present in raw material and in delignified solids, respectively and $S Y$ is the solid yield of pretreatment.

The delignification results were included in Table 3 . The highest percentages of delignification ( $>50 \%$ ) were achieved at temperature of $192.5^{\circ} \mathrm{C}$, time $>68 \mathrm{~min}$ and percentage of ethanol-water of $52 \%$ (corresponding to experiment 4 and 6). On the other hand, the lowest delignification percentages $(<26 \%)$ were obtained at $177.5^{\circ} \mathrm{C}$, showing a clear effect of temperature on the solubilization of xylan and 
lignin. The effect of temperature increase on the decrease of pulp yield, mainly due to xylan and lignin solubilization, was also reported by Wildschut and co-workers (2013) using ethanol organosolv fractionation process for the delignification of wheat straw. The temperature also had a positive effect on lignin recovery of catalytic ethanol-water organosolv delignification of palm fronds (Cybulska et al., 2017).

After organosolv treatment, the black liquor was analysed for quantification of hemicellulose-derived compounds, mainly sugars (glucose and xylose). Table 3 also provides the data concerning the chemical composition of the liquid phase (black liquors). Low glucose concentrations $(<1.30 \mathrm{~g} / \mathrm{L})$ were quantified in liquid phases, which shows a low degradation of glucan by organosolv treatment. However, the presence of xylan-derived compounds (which would include both xylooligosaccharides and xylose) in the reaction media was higher, as demonstrated by the xylose concentrations (also quantified after acid hydrolysis of black liquors). Xylose concentration in organosolv liquors varied in the range 3.8-9.1 g/L (see experiments 2 and 10), corresponding to xylan recovery in the solid phase of $40-86 \%$.

\subsection{Simultaneous saccharification and fermentation of delignified ENB}

Delignified ENB obtained from organosolv treatment was used as substrate for ethanol production by simultaneous saccharification and fermentation (SSF) process. Ethanol concentration varied in the range of 8.91-32.5 g/L (corresponding to experiment 9 and 4, respectively). In SSF experiments, the xylose concentration (up to $4 \mathrm{~g} / \mathrm{L}$ ) was also quantified (data not shown) that corresponded to $24 \%$ of xylose yield from xylan of delignified pulp. Clear differences in the ethanol production were observed among experiments showing the influence of organosolv conditions. Additional SSF assay with untreated Eucalyptus nitens bark was carried out (data not shown). In this experiment, ethanol was not detected, which shows the importance of the pretreatment for the enhancement of enzymatic saccharification (Alvira et al., 2010).

Time course of ethanol yield from SSF assays (calculated following the Eq. (1)) was displayed in Fig. 1. Ethanol Yields, ranged from 31.5 to $98.7 \%$, were obtained for ENB treated at $65 \%$ of ethanol-water and $177.5^{\circ} \mathrm{C}$ for $34 \mathrm{~min}$ and $192.5^{\circ} \mathrm{C}$ for $86 \mathrm{~min}$, (denoted as experiment 9 and 4 in Table 3). These results showed a huge improvement of ethanol production from delignified eucalyptus bark, which was influenced by an increase of temperature and time (Fig. 1 and results listed in Table 3). Additionally, in the entire experimental conditions evaluated, the highest ethanol yields ( $>80 \%$ ) were obtained from solids pretreated at intermediate percentages of ethanol and intermediate to high temperatures and times $\left(200^{\circ} \mathrm{C}\right.$ for $60 \mathrm{~min}$ and $192.5^{\circ} \mathrm{C} 86 \mathrm{~min}$, see experiments 1 and 4 in Fig. 1a). Additionally, organosolv pretreatments performed at low percentages of ethanol, intermediate temperatures and low to medium reaction times, as for example experiments 6 and 11 , also allowed reaching interesting ethanol yields (close to $60 \%$ ). On the other hand, ethanol yields $<36 \%$ were achieved when organosolv process was carried out at temperatures between $170-192.5^{\circ} \mathrm{C}$ for 34 and $60 \mathrm{~min}$ and $65 \%$ ethanol-water.

As general trend, the maximal ethanol concentrations were achieved within $9 \mathrm{~h}$ of SSF assays. These results can be positively compared to literature, in which the optimum reaction time for the SSF of pretreated leaves of Antigonum leptopus was $24 \mathrm{~h}$ (Krishna and Chowdary, 2000). Therefore, ethanol productivity (Qp) was calculated at $9 \mathrm{~h}$ of fermentation and varied in the range $0.89-2.83 \mathrm{~g} / \mathrm{Lh}$. Organosolv delignification process allowed the improvement of pulp susceptibility to enzymatic hydrolysis and further fermentation of glucose into ethanol, as observed for the high ethanol productivities obtained in this work. These results can be positively compared with the ones reported in the literature, in which $1.9 \mathrm{~g} / \mathrm{Lh}$ of volumetric productivity was achieved after a presaccharification and fermentation of pretreated birch using a steam explosion organosolv treatment (Matsakas et al., 2018).
Finally, from the experimental results, it should be noted that the SSF of the solid obtained in experiment 4 (65\% of ethanol-water and $192.5^{\circ} \mathrm{C}$ for $86 \mathrm{~min}$ ) resulted in the highest ethanol concentration and ethanol yield after $30 \mathrm{~h}$, and the highest Qp at $9 \mathrm{~h}(32.5 \mathrm{~g} / \mathrm{L}, 98.7 \%$ and $2.83 \mathrm{~g} / \mathrm{L}$ h, respectively).

In comparison with literature, few works have studied the pretreatment effect on enhancing of enzymatic saccharification of eucalyptus bark (Matsushita et al., 2010; Lima et al., 2013). In these works, $80 \%, 7.4 \%$ and $98.6 \%$ of glucose yields were obtained using hydrothermal treatment with $\mathrm{CO}_{2}$, liquid hot water and alkali pretreatments, respectively. Lima and co-workers (2013) compared the liquid hot water, acid and alkali pretreatments of $E$. grandis and $E$. grandis $x$ urophylla barks for glucose production, showing the highest digestibility of cellulose by delignification process using $4 \% \mathrm{NaOH}$ at $120^{\circ} \mathrm{C}$ for $60 \mathrm{~min}$. Delignification treatments (such as alkali and organosolv) removed significant lignin and hemicelluloses increasing the access to surface area, which improved the enzymatic saccharification of cellulose (Rabindran and Jaismal, 2016). Moreover, delignification processes increase the cellulose content in the pretreated lignocellulosic biomass, which is determinant to obtain high concentration of final product (Zhao et al., 2017). Recently, the enzymatic saccharification of E. nitens wood pretreated by consecutives autohydrolysis and pulping stages was evaluated for glucose production achieving cellulose to glucose conversions $>88 \%$ at 60 h of saccharification (Penin et al., 2018).

Moreover, recent works showed the optimization of bioethanol production from delignified Eucalyptus globulus wood pretreated by organosolv using ethanol and glycerol as solvents (Muñoz et al., 2011; Romaní et al., 2016). The results obtained in this work can be positively compared with the ones reported in literature using $\mathrm{SO}_{2}$-catalyzed steam pretreated spruce bark, in which $87 \%$ of ethanol yield was obtained by separate hydrolysis and fermentation (SHF) (Frankó et al., 2015). The whole Eucalyptus grandis tree (including barks, branches and leaves) was pretreated by steam explosion and used as substrate for ethanol production, achieving an ethanol yield of $90 \%$ using $20 \%$ of solids and $60 \mathrm{FPU} / \mathrm{g}$ (McIntosh et al., 2017). As far as we know, there are no studies for bioethanol production from E. nitens bark using an organosolv process. This is the first work showing a suitable process for the efficient bioethanol production from Eucalyptus bark (ethanol yield of $98.7 \%)$.

\subsection{Response surface methodology assessment of organosolv fractionation and SSF of ENB}

Response surface methodology (RSM) was proposed for an easier interpretation of results obtained from organosolv fractionation and SSF assays. Dependent variables (listed in Table 3 , from $\mathrm{y}_{1}$ to $\mathrm{y}_{6}$ ) were correlated with independent variables (temperature, time and ethanolwater percentage) by empirical models, as follows:

$y_{j}=b_{0 j}+\sum_{i=1}^{2} b_{i j} x_{i}+\sum_{i=1}^{2} \sum_{k \geq i}^{2} b_{i k j} x_{i} x_{k}$

where $y_{j}(j=1$ to 6$)$ is the dependent variable; $x_{i}$ or $x_{k}$ (i or $k$ : 1 to 3 , $k \geq i$ ) are the normalized, independent variables (defined in Table 2), and $b_{0 j} \ldots b_{i k j}$ are regression coefficients calculated from experimental data by multiple regression using the least-squares method. The experimental data were fitted to the proposed models using commercial software (Microsoft Excel, Microsoft, USA).

Fitting parameters were listed in Table 4, showing the good fittingness of the empirical models. Regression coefficients, the statistical significance (based on the Students $t$ test) and the statistical significance of model (Fischer's $F$ parameter) were also included in Table 4. The correlation coefficient $\left(R^{2}\right)$ of the models varied from 0.88 to 0.99 that indicates the appropriate relationships among the selected variables.

The predicted values for variables SY $\left(y_{1}\right)$, percentage of 
a)

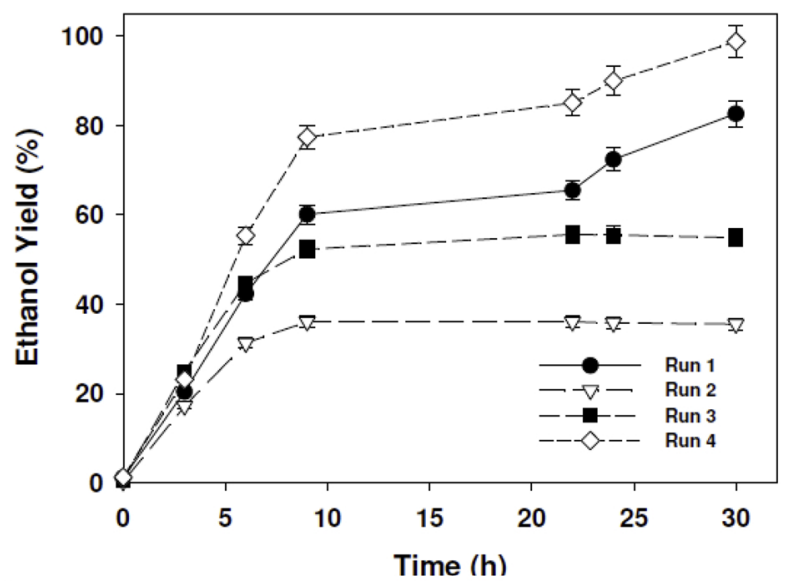

c)

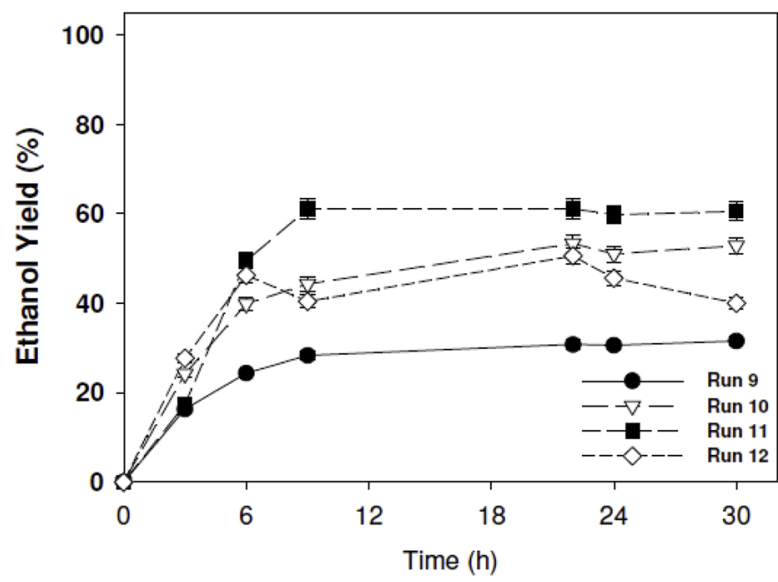

b)



d)

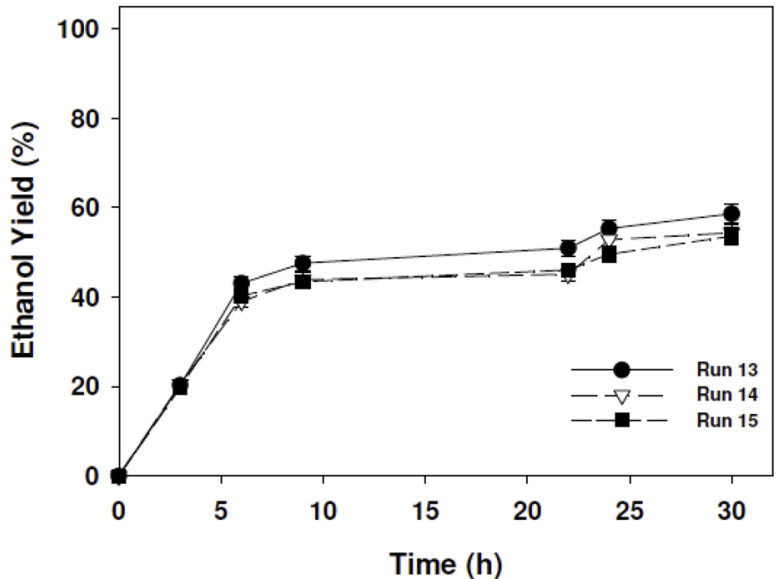

Fig. 1. Time course of ethanol yield (YEt) from simultaneous saccharification and fermentation assays of delignified Eucalyptus nitens barks.

delignification $\left(y_{2}\right)$ and glucan and xylan recoveries $\left(y_{3}\right.$ and $\left.y_{4}\right)$ at 50, 65 and $80 \%$ of ethanol-water were displayed in Fig. 2. As observed in Fig. 2a, SY increased with the ethanol-water percentage and with the decrease of temperature. On the other hand, the lowest SY $(52.71 \%)$ was achieved at the highest temperature and time evaluated. These results are inversely related to the percentage of delignification, shown in Fig. 2b, in which the highest delignification of $62.2 \%$ was predicted $\left(200^{\circ} \mathrm{C}, 90 \mathrm{~min}\right.$ and $50 \%$ of ethanol-water). As observed in Table 4, the linear coefficients for $\mathrm{y}_{1}$ and $\mathrm{y}_{2}$ were significant at $p \leq 0.05$ for temperature, time and percentage of ethanol-water. The ethanol concentration higher than $70 \%$ decreases the lignin solubility in waterethanol mixtures (Asadi and Zilouei, 2017).

On the other hand, Fig. 2c shows a glucan recovery higher than $86 \%$ at $30 \mathrm{~min}$ of organosolv treatment in the range of temperature evaluated $\left(170-200^{\circ} \mathrm{C}\right)$. On the other hand, high cellulose loss (glucan recovery $<79 \%$ ) was predicted at temperature $>185^{\circ} \mathrm{C}$ and time $>$ $50 \mathrm{~min}$ using $80 \%$ of ethanol-water. Similar glucan recoveries were reported for the catalyzed delignification process of prairie cordgrass using an organic solvent-aqueous mixture contained methyl isobutyl ketone, ethanol and water (Brudecki et al., 2012). The highest xylan recovery obtained in this work was predicted at lowest time $(30 \mathrm{~min}$ ) and temperature $\left(170{ }^{\circ} \mathrm{C}\right)$ using $50 \%$ of ethanol-water as solvent (Fig. 2d). The xylan recovery greatly decreased with the raise of temperature. The effect of high temperature, high catalyst level or a combination of two on the lowest xylan recovery was also reported for the delignification of prairie cordgrass (Brudecki et al., 2012).

Regarding the ethanol production from simultaneous saccharification process of delignified ENB, maximal ethanol concentration and ethanol yield were also listed in Table 3. Fig. 3 shows the graphic representation of temperature and time effect on ethanol concentration

Table 4

Regression coefficients and statistical parameters measuring the correlation and significance of the models.

\begin{tabular}{|c|c|c|c|c|c|c|c|c|c|c|c|c|c|}
\hline Coefficient & $b_{0 j}$ & $b_{1 j}$ & $\mathrm{~b}_{2 \mathrm{j}}$ & $b_{3 j}$ & $b_{11 j}$ & $\mathrm{~b}_{22 \mathrm{j}}$ & $b_{33 j}$ & $b_{12 j}$ & $b_{13 j}$ & $b_{23 j}$ & $\mathrm{R}^{2}$ & $\mathrm{~F}$ & significance level(\%) \\
\hline $\mathrm{y}_{1}$ & $62.94^{\mathrm{a}}$ & $-8.45^{\mathrm{a}}$ & $-5.36^{\mathrm{a}}$ & $6.80^{\mathrm{a}}$ & $6.49^{\mathrm{a}}$ & $3.51^{\mathrm{b}}$ & -1.59 & $-3.94^{\mathrm{b}}$ & $-5.62^{\mathrm{b}}$ & -0.27 & 0.990 & 53.1 & 99.98 \\
\hline $\mathrm{y}_{2}$ & $40.24^{\mathrm{a}}$ & $10.87^{\mathrm{a}}$ & $5.89^{\mathrm{a}}$ & $-7.98^{\mathrm{a}}$ & -2.52 & 0.10 & -1.10 & $4.52^{c}$ & 1.92 & 1.84 & 0.987 & 41.5 & 96.78 \\
\hline $\mathrm{y}_{3}$ & $79.92^{\mathrm{a}}$ & -2.11 & -1.90 & $2.98^{\mathrm{c}}$ & $9.57^{\mathrm{b}}$ & $6.75^{\mathrm{b}}$ & $-5.19^{c}$ & -6.30 & -7.82 & -0.33 & 0.909 & 5.6 & 96.32 \\
\hline $\mathrm{y}_{4}$ & $49.00^{\mathrm{a}}$ & $-24.65^{\mathrm{a}}$ & $-14.60^{\mathrm{a}}$ & $20.09^{\mathrm{a}}$ & 9.08 & 6.56 & -0.36 & 6.37 & 0.70 & -16.35 & 0.96 & 13.69 & 99.49 \\
\hline $\mathrm{y}_{5}$ & $16.82^{\mathrm{a}}$ & $8.61^{\mathrm{a}}$ & $5.56^{\mathrm{b}}$ & $-5.34^{b}$ & 2.23 & 1.91 & -4.16 & 4.41 & -1.94 & 0.72 & 0.924 & 6.8 & 98.77 \\
\hline $\mathrm{y}_{6}$ & $55.55^{\mathrm{a}}$ & $22.32^{\mathrm{a}}$ & $14.99^{\mathrm{b}}$ & $-14.36^{\mathrm{b}}$ & 3.52 & 4.47 & -12.61 & 12.35 & -3.22 & 3.47 & 0.883 & 4.2 & 93.56 \\
\hline
\end{tabular}

a Coefficients significant at the $99 \%$ confidence level.

b Coefficients significant at the $95 \%$ confidence level.

${ }^{c}$ Coefficients significant at the $90 \%$ confidence level. 
a)



Ethanol-water $=80 \%$

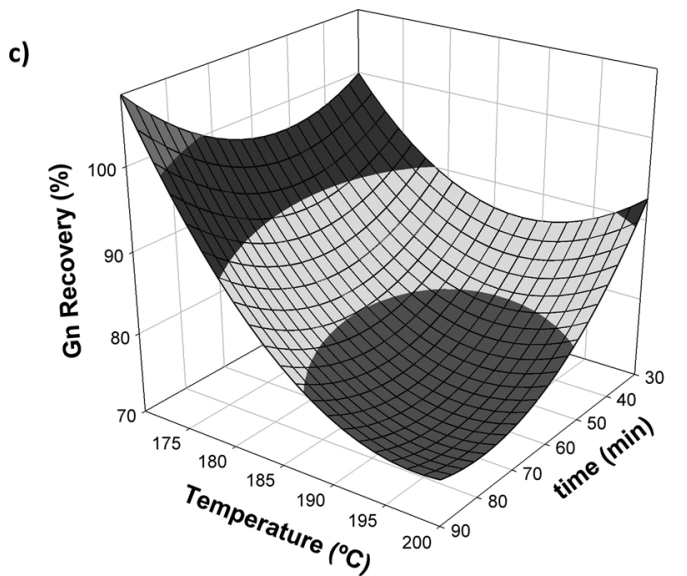

b)

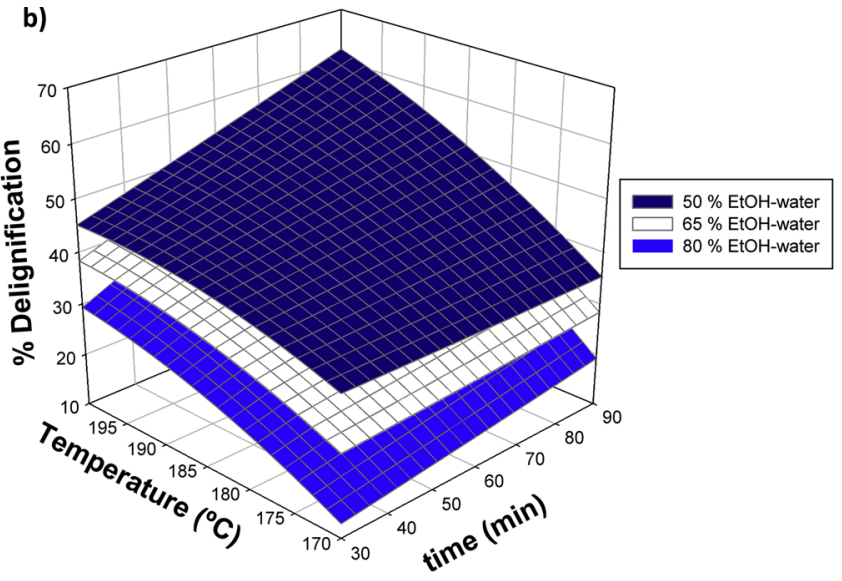

Ethanol-water $=50 \%$

d)

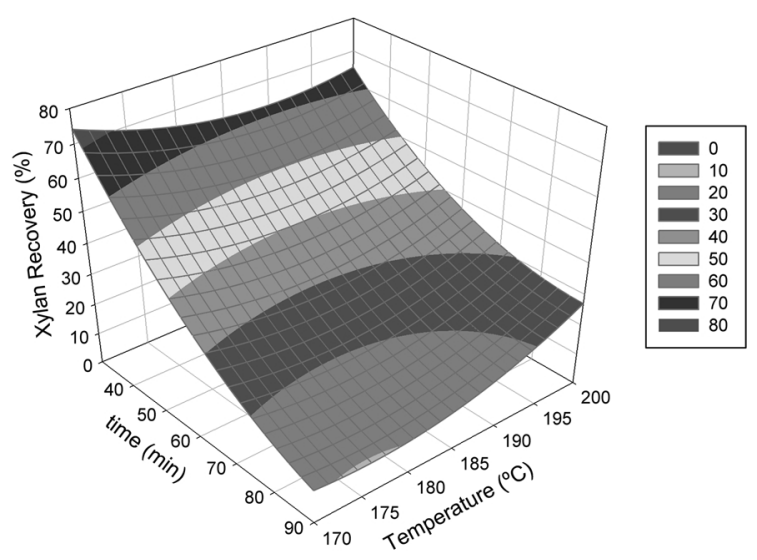

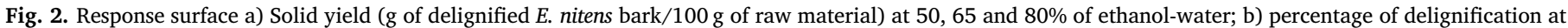
50,65 and $80 \%$ of ethanol-water; c) glucan recovery ( $g$ of glucan fixed ethanol-water at $80 \%$ and d) xylan recovery, fixed ethanol-water at 50\%.

and ethanol yield with 50, 65 and $80 \%$ of ethanol-water. As observed, the increase of temperature and time influenced positively on ethanol concentration. This effect was more prominent at ethanol-water of 50 and $65 \%$. The percentage of ethanol-water had a negative effect on ethanol concentration and yield. Similar behavior on glucose yield was also observed in the delignification of Eucalyptus globulus wood by glycerol-water treatment (Romaní et al., 2013). The linear coefficient was significant at $p<0.05$ for temperature, time and ethanol-water percentage (Table 4). Higher ethanol concentration than $40 \mathrm{~g} / \mathrm{L}$ was predicted by the models at $50-60 \%$ of ethanol-water, temperature $>$ $197^{\circ} \mathrm{C}$ and time $>86 \mathrm{~min}$. This concentration is desirable since $4 \%$ of ethanol was identified as critical for the distillation costs improving the economics of process for concentrations above this threshold (Zacchi and Axelsson, 1989). On other hand, ethanol yield $>80 \%$ was achieved at temperature $>175{ }^{\circ} \mathrm{C}$ and $90 \mathrm{~min}$ using $50 \%$ of ethanol-water. At 65 and $80 \%$ of ethanol-water, the temperature necessary to achieve $80 \%$ of ethanol yield was 175 and $194^{\circ} \mathrm{C}$ for $90 \mathrm{~min}$, respectively.

\section{Conclusions}

In this work, a waste from pulp and paper industry (Eucalyptus nitens bark) was characterized and processed by alternative organosolv delignification process. The percentage of ethanol-water of $50 \%$ allowed a $62 \%$ of delignification. The most significant variables for the delignification process were temperature and time. Moreover, in a wide range of conditions, higher than $90 \%$ of glucan was recovered in the solid phase. This pretreatment significantly enhanced the simultaneous saccharification and fermentation process for ethanol production (from 32 to $96 \%$ of ethanol yield). Moreover, the reaction time for SSF was significantly reduced, achieving high ethanol productivities $(2.83 \mathrm{~g}$ / Lh). Under selected conditions, the cellulosic pulp of Eucalyptus nitens bark was converted into ethanol to yield $252 \mathrm{~L}$ of ethanol/ton of ovendry biomass (corresponding to $77.45 \%$ of theoretical ethanol yield) and $113 \mathrm{~kg}$ of lignin/ton and $72 \mathrm{~kg}$ of xylose/ton were also recovered in separate streams. To our knowledge, for the first time, Eucalyptus nitens bark is used for efficient ethanol production. In addition, the proposed treatment allows the integral valorization of Eucalyptus bark by additional recovery of lignin with high purity and hemicellulose as xylose in separate streams, which can be further valorized contributing for the feasibility of the overall process.

\section{Acknowledgements}

This study was supported by the Portuguese Foundation for Science and Technology (FCT) under the scope of the strategic funding of UID/ BIO/04469/2019 unit, BioTecNorte operation (NORTE-01-0145FEDER-000004) funded by the European Regional Development Fund under the scope of Norte2020 - Programa Operacional Regional do Norte, the MultiBiorefinery project (POCI-01-0145-FEDER-016403) and EcoTech project (POCI-01-0145-FEDER-032206). Antonio Larramendi thanks to Iacobus program for the mobility fellowship. 


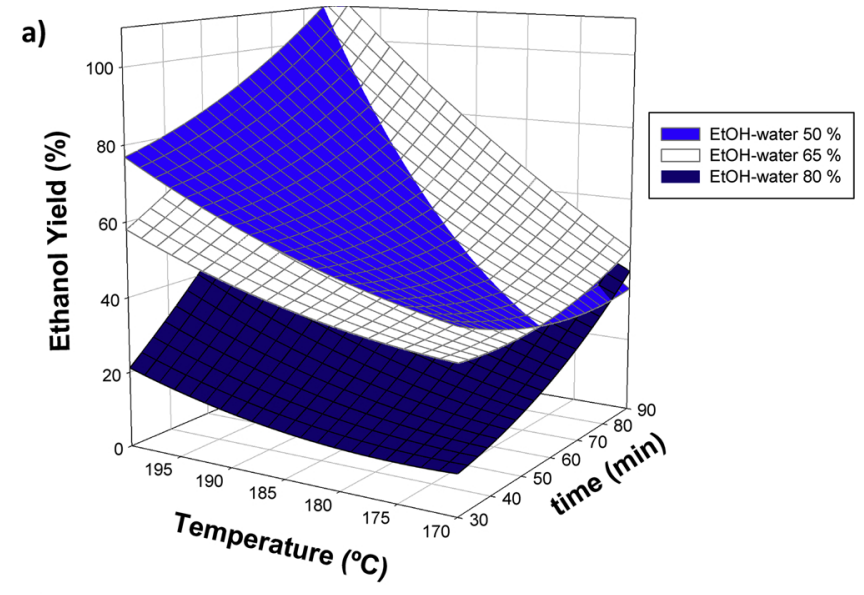

b)

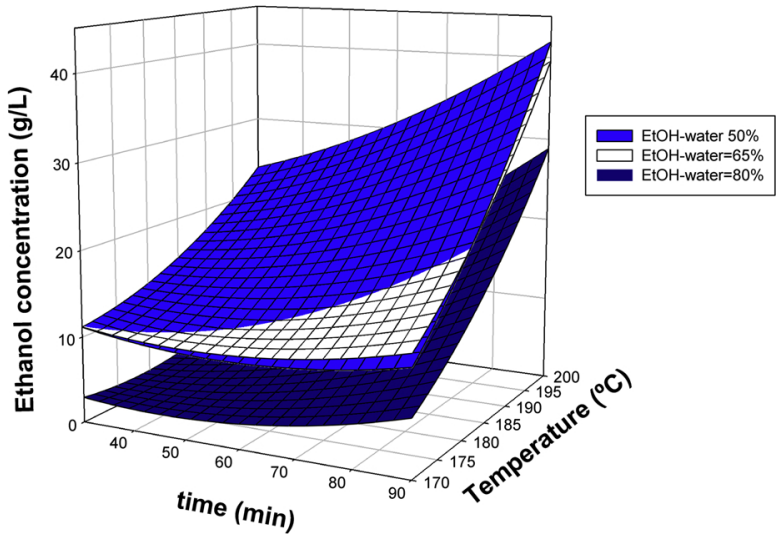

Fig. 3. Response surface a) ethanol concentration $(\mathrm{g} / \mathrm{L})$ at 50,65 and $80 \%$ of ethanol-water; and b) ethanol yield (\%) at 50, 65 and $80 \%$ of ethanol-water.

\section{Appendix A. Supplementary data}

Supplementary data associated with this article can be found, in the online version, at https://doi.org/10.1016/j.indcrop.2019.02.040.

\section{References}

Alvira, P., Tomás-Pejó, E., Ballesteros, M., Negro, M.J., 2010. Pretreatment technologies for an efficent bioetanol production process based on enzymatic hydrolysis: a review. Bioresour. Technol. 101, 4851-4861.

Asadi, N., Zilouei, H., 2017. Optimization of organosolv pretreatment of rice straw for enhanced biohydrogen production using Enterobacter aerogenes. Bioresour. Technol. 227, 335-344.

Bailey, M.J., Biely, P., Poutanen, K., 1992. Interlaboratory testing of methods for assay of xylanase activity. J. Biotechnol. 23, 257-270.

Brudecki, G., Cybulska, I., Rosentrater, K., Julson, J., 2012. Optimization of clean fractionation processing as a pre-treatment technology for prairie cordgrass. Bioresour. Technol. 107, 494-504.

Caldas, L.F.S., de Paula, C.E.R., Brum, D.M., Cassella, R.J., 2013. Application of a fourvariables Doehlert design for the multivariate optimization of copper determination in petroleum-derived isulating oils by GFAAS employing the dilute-and-shot approach. Fuel 105, 503-511.

Canettieri, E.V., Rocha, G.J.M., de Carvalho Jr, J.A., de Almeida e Silva, J.B., 2007. Optimization of acid hydrolysis from the hemicellulosic fraction of Eucalyptus grandis residue using response surface methodology. Bioresour. Technol. 98, 422-428.

Chen, H.Z., Xu, J., Li, Z.H., 2007. Temperature cycling to improve the ethanol production with solid state simultaneous saccharification and fermentation. Appl. Biochem. Microbiol. 43 (1), 57-60.

Cybulska, I., Brudecki, G.P., Zembrzuska, J., Schmidt, J.E., Lopez, C.G.B., Thomsen, M.H., 2017. Organosolv delignification of agricultural residues (date palm fronds, Phoenix dactylifera L.) of the United Arab Emirates. Appl. Energy 185, 1040-1050.

Dafnomilis, I., Hoefnagels, R., Pratama, Y.W., Schott, D.L., Lodewijks, G., Junginger, M., 2017. Review of solid and liquid biofuel demand and supply in Northwest Europe towards 2030 - a comparison of national and regional projections. Renew. Sust. Energy Rev. 31-45.

Dávila, I., Gullón, P., Andrés, M.A., Labidi, J., 2017. Coproduction of lignin and glucose from vine shoots by eco-friendly strategies: toward the development of an integrated biorefinery. Bioresour. Technol. 244, 328-337.
Domec, J.-C., Ashley, E., Fischer, M., Noormets, A., Boone, J., Williamson, J.C., King, J.S., 2017. Productivity, biomass partitioning, and energy yield of low-input short-rotation American sycamore (Platanus occidentalis L.) grown on marginal land: effects of planting density and simulated drought. Bioenergy Res. 10, 903-914.

Domínguez, E., Romaní, A., Alonso, J.L., Parajó, J.C., Yáñez, R., 2014. A biorefinery approach based on fractionation with a cheap industrial by-product for getting value from an invasive woody species. Bioresour. Technol. 173, 301-308.

El Hage, R., Brosse, N., Navarrete, P., Pizzi, A., 2011. Extraction, characterization and utilization of organosolv Miscanthus lignin for the conception of environmentally friendly mixed tannin/lignin wood resins. J. Adhesion. Sci. Technol. 25, 1549-1560.

Flynn, B., 2010. Eucalyptus: Having an Impact on the Global Solid Wood Industry. Wood Resources International. http://www.wri-ltd.com/marketPDFs/Eucalyptus.pdf.

Foelkel, C., 2010. Eucalyptus Online Book. http://www.eucalyptus.com.br.

Frankó, B., Galbe, M., Wallberg, O., 2015. Influence of bark on fuel ethanol production from steam-pretreated spruce. Biotechnol. Biofuels 8, 15.

Galbe, M., Zacchi, G., 2007. Pretreatment of lignocellulosic materials for efficient bioethanol production. Adv. Biochem. Eng. Biotechnol. 108, 41-65.

Garrote, G., Domínguez, H., Parajó, J.C., 1999. Mild autohydrolysis: an environmentally friendly technology for xylooligosaccharide production from wood. J. Chem. Technol. Biotechnol. 74, 1101-1109.

Ghose, T.S., 1987. Measurement of cellulose activities. Pure Appl. Chem. 59 (2), 257-268.

González-García, M., Hevia, A., Majada, J., Barrio-Anta, M., 2013. Above-ground biomass estimation at tree and stand level for short rotation plantations of Eucalyptus nitens (Deane \& Maiden) Maiden in Northwest Spain. Biomass Bioenergy 54, 147-157.

Huijgen, W.J.J., Smit, A.T., Reith, J.H., den Uil, H., 2011. Catalytic organosolv fractionation of willow wood and wheat strar as pretreatment for enzymatic cellulose hydrolysis. J. Chem. Technol. Biotechnol. 86, 1428-1438.

Kim, Y., Yu, A., Han, M., Choi, G.W., Chung, B., 2010. Ethanosolv pretreatment of barley straw with iron(III) chloride for enzymatic saccharification. J. Chem. Technol. Biotechnol. 85, 1494-1498.

Krishna, S.H., Chowdary, G.V., 2000. Optimization of Simultaneous Saccharification and Fermentation for the Production of Ethanol From Lignocellulosic Biomass.

Kumar, A.K., Sharma, S., 2017. Recent updates on different methods of pretreatment of lignocellulosic feedstocks: a review. Bioresour. Bioprocess. 4 (7).

Küüt, A., Ilves, R., Küüt, K., Raide, V., Ritslaid, K., Olt, J., 2017. Influence of European Union Directives on the use of liquid biofuel in the transport sector. Procedia Eng. 187, 30-39.

Li, C., Sun, L., Simmons, B.A., Singh, S., 2013. Comparing the recalcitrance of eucalyptus, pine and switchgrass using ionic liquid and dilute acid pretreatments. Bioenergy Res. 6, 14-23.

Lima, M.A., Lavorente, G.B., da Silva, H., Bragatto, J., Rezende, C.A., Bernardinelli, O.D., de Azevedo, E.R., Gomez, L.D., McQueen-Mason, S., Labate, C.A., Polikarpov, I., 2013. Effects of pretreatment on morphology, chemical composition and enzymatic digestibility of eucalyptus bark: a potentially valuable source of fermentable sugars for biofuel production - part 1. Biotechnol. Biofuels.

Lima, M.A., Gomez, L.D., Steele-King, C.G., Simister, R., Bernardinelli, O.D., Carvalho, M.A., Rezende, C.A., Labate, C.A., deAzevedo, E.R., McQueen-Mason, S.J. Polikarpov, I., 2014. Evaluating the composition and processing potential of novel sources of Brazilian biomass for sustainable biorenewables production. Biotechnol. Biofuels 7, 10.

Martín, C., Puls, J., Saake, B., Schreiber, A., 2011. Effect of glycerol pretreatment on component recovery and enzymatic hydrolysis of sugarcane bagasse. Cellul. Chem. Technol. 45, 487-494.

Matsakas, L., Nitsos, C., Raghavendran, V., Yakimenko, O., Persson, G., Olsson, E., Rova, U., Olsson, L., Christakopoulos, P., 2018. A novel hybrid organosolv: steam explosion method for the efficient fractionation and pretreatment of birch biomass. Biotechnol. Biofuels 11, 160

Matsushita, Y., Yamauchi, K., Takabe, K., Awano, T., Yoshinaga, A., Kato, M., Kobayashi, T., Asada, T., Furujyo, A., Fukushima, K., 2010. Enzymatic saccharification of Eucalyptus bark using hydrothermal pre-treatment with carbon dioxide. Bioresour. Technol. 101, 4936-4939.

McIntosh, S., Palmer, J., Zhang, Z., Doherty, W.O.S., Yazdani, S.S., Sukumaran, R.K. Vancov, T., 2017. Simultaneous saccharification and fermentation of pretreated Eucalyptus grandis under high solids loadings. Ind. Biotechnol. New Rochelle N. (New Rochelle N Y) 13 (3), 131-140.

Moshkelani, M., Marinova, M., Perrier, M., Paris, J., 2013. The forest biorefinery and its implementation in the pulp and paper industry: energy overview. App. Therm. Eng. $50,1427-1436$.

Muñoz, C., Mendonça, R., Baeza, J., Berlin, A., Saddler, J., Freer, J., 2007. Bioethanol production from bio-organosolv pulps of Pinus radiata and Acacia dealbata. J. Chem. Technol. Biotechnol. 82, 767-774.

Muñoz, C., Baeza, J., Freer, J., Mendonça, R.T., 2011. Bioethanol production from tension and opposite wood of Eucalyptus globulus using organosolv pretreatment and simultaneous saccharification and fermentation. J. Ind. Microbiol. Biotechnol. 38, 1861-1866.

Neiva, D.M., Araújo, S., Gominho, J., Carneiro, A.D.C., Pereira, H., 2018. Potential of Eucalyptus globulus industrial bark as biorefinery feedstock: chemical and fuel characterization. Ind. Crop. Prod. 123, 262-270.

Novo, L.P., Gurgel, L.V.A., Marabezi, K., Curvelo, A.A.D.S., 2011. Delignification of sugarcane bagasse using glycerol-water mixtures to produce pulps for saccharification. Bioresour. Technol. 102, 10040-10046.

Pan, X., Gilkes, N., Kadla, J., Pye, K., Saka, S., Gregg, D., Ehara, K., Xie, D., Lam, D., Saddler, J., 2006. Bioconversion of hybrid poplar to ethanol and co-products using an organosolv fractionation process: optimization of process yields. Biotechnol. Bioeng. 94, 851-861.

Penín, L., Peleteiro, S., Santos, V., Alonso, J.L., Parajó, J.C., 2018. Selective Fractionation 
and Enzymatic Hydrolysis of Eucalyptus nitens Wood. Cellulose. In press. .

Pereira, F.B., Romaní, A., Ruiz, H.A., Teixeira, J.A., Domingues, L., 2014. Industrial robust yeast isolates with great potential for fermentation of lignocellulosic biomass. Bioresour. Technol. 161, 192-199.

Pérez, S., Renedo, C.J., Ortiz, A., Mañana, M., Silió, D., 2006. Energy evaluation of the Eucalyptus globulus and the Eucalyptus nitens in the north of Spain (Cantabria). Thermochim. Acta 451, 57-64.

Rabindran, R., Jaismal, A.K., 2016. A comprehensive review on pre-treatment strategy for lignocellulosic food industry waste: challenges and opportunities. Bioresour. Technol. 199, 92-102.

Reina, L., Botto, E., Mantero, C., Moyna, P., Menéndez, P., 2016. Production of second generation ethanol using Eucalyptus dunnii bark residues and ionic liquid pretreatment. Biomass Bioenery 93, 116-121.

Rodríguez-López, J., Sánchez, A.J., Gómez, D.M., Romaní, A., Parajó, J.C., 2012. Fermentative production of fumaric acid from Eucalyptus globulus wood hydrolyzates. J. Chem. Technol. Biotechnol. 87, 1036-1040.

Rohowsky, B., Häßler, T., Gladis, A., Remmele, E., Schieder, D., Faulstich, M., 2013. Feasibility of simultaneous saccharification and juice co-fermentation on hydrothermal pretreated sweet sorghum bagasse for ethanol production. Acs Appl. Energy Mater. 102, 211-219.

Romaní, A., Garrote, G., Alonso, J.L., Parajó, J.C., 2010. Bioethanol production from hydrothermally pretreated Eucalyptus globulus wood. Bioresour. Technol. 101 (22), $8706-8712$

Romaní, A., Garrote, G., López, F., Parajó, J.C., 2011. Eucalyptus globulus wood fractionation by autohydrolysis and organosolv delignification. Bioresour. Technol. 102, 5896-5904.

Romaní, A., Ruiz, H.A., Pereira, F.B., Domingues, L., Teixeira, J.A., 2013. Fractionation of Eucalyptus globulus wood by glycerol-water pretreatment: optimization and modeling. Ind. Eng. Chem. Res. 52 (40), 14342-14352.

Romaní, A., Ruiz, H.A., Teixeira, J.A., Domingues, L., 2016. Valorization of Eucalyptus wood by glycerol-organosolv pretreatment within the biorefinery concept: an integrated and intensified approach. Renew. Energy 95, 1-9.

Ruiz, H.A., Rodríguez-Jasso, R.M., Fernandes, B.D., Vicente, A.A., Teixeira, J.A., 2013 Hydrothermal processing, as an alternative for upgrading agriculture residues and marine biomass according to the biorefinery concept: a review. Renew. Sust. Energy Rev. 21, 35-51.

Saberikhah, E., Rovshandeh, J.M., Rezayati-Charani, P., 2011. Organosolv pulping of wheat straw by glycerol. Cellul. Chem. Technol. 45, 67-75.

Toledano, A., Serrano, L., Labidi, J., 2011. Enhancement of lignin production from olive tree pruning intregrated in a Green biorefinery. Ind. Eng. Chem. Res. 50, 6573-6579.

Toledano, A., Serrano, L., Labidi, J., 2012. Organosolv lignin depolymerization with different base catalysts. J. Chem. Technol. Biotechnol. 87, 1593-1599.

Wildschut, J., Smit, A.T., Reith, J.H., Huijgen, W.J.J., 2013. Ethanol-based organosolv fractionation of wheat straw for the production of lignin and enzymatically digestible cellulose. Bioresour. Technol. 135, 58-66.

Yáñez-S, M., Rojas, J., Castro, J., Ragauskas, A., Baeza, J., Freer, J., 2013. Fuel ethanol production from Eucalyptus globulus wood by autocatalized organosolv pretreatment ethanol-water and SSF. J. Chem. Technol. Biotechnol. 88, 39-48.

Zacchi, G., Axelsson, A., 1989. Economic evaluation of preconcentration in production of ethanol from dilute sugar solutions. Biotechnol. Bioeng. 20 (34(2)), 223-2233.

Zakzeski, J., Jongerius, A.L., Bruijnincx, P.C.A., Weckhuysen, B.M., 2012. Catalytic lignin valorization process for the production of aromatic chemicals and hydrogen. ChemSusChem 5 (8), 1602-1609.

Zhao, X., Li, S., Wu, R., Liu, D., 2017. Organosolv fractionating pre-treatment of lignocellulosic biomass for efficient enzymatic saccharification: chemistry, kinetics, and substrate structures. Biofuels Bioprod. Bioref. 11, 567-590.

Zhu, J.Y., Pan, X.J., 2010. Woody biomass pretreatment for cellulosic ethanol production: technology and energy consumption evaluation. Bioresour. Technol. 101, 4992-5002. 